\title{
High-efficiency treatment of low-sulfate in wastewater by a sort of SRB
}

\author{
Xiaoye Liu ${ }^{\mathrm{a}}$, Shanzhi Xin ${ }^{\mathrm{b}}$ \\ School of chemical and Environmental engineering, Jianghan University, China \\ a1024xiaoye@163.com, b271696039@qq.com
}

Keywords: sulfate-reducing bacteria, reducing characteristics, low sulfate concetration

\begin{abstract}
Biological treatment with sulfate-reducing bacteria (SRB) has been considered as the most promising alternative for acid mine drainage (AMD) pollution control. Here we reported some characteristics of SRB, which was isolated from sulfate rich and low $\mathrm{pH}$ waste water. It was a sulfate-tolerant bacterium. In the neutral postgate's $C$ medium at the inoculation ratio of 1:10, and in low concentration of sulfate waster when $\mathrm{C} / \mathrm{S}$ ratios was about 2.0, the sulfate removal ratio could reach more than $80 \%$. As the sulfate concentration increased, the absolute amount of sulfate removal also increased, but its removal ratio decreased. The characteristics would provide some information for the researchers to study this sort of bacteria.
\end{abstract}

\section{Introduction}

Bioremediation of acidic wastewaters from mining industries is concerned worldwide. The main characteristics of acid mining drainage (AMD) are low $\mathrm{pH}(\mathrm{pH}<4)$ and elevated concentrations of sulfate and dissolved metals. The remediation of acidic mine wastewaters can be achieved by applying continuous alkaline matter such as limestone and so on to neutralize low $\mathrm{pH}$ waters and precipitate metals. However, there must be a great cost for the remediation [1].

Recently, many researchers focus on the anaerobic bacteria SRB to solve the problem of AMD. The sulfate ion $\left(\mathrm{SO}_{4}{ }^{2-}\right)$ could be reduced to sulfide $\left(\mathrm{S}^{2-}\right)$ by this sort of bacteria reported in [2]. In this case, the application of SRB in AMD could enhance the $\mathrm{pH}$ by producing $\mathrm{H}_{2} \mathrm{~S}$ and precipitate metals by forming metal sulfide (MS), which can be easily separated and recycled as reported by [3]. Therefor the cultivation of SRB becomes a popular topic for researchers to investigate.

Many researchers found that AMD could be treated by reactors with SRB bacterium. In the research of [4], the sulfate removal ratio in column reactor was about $50 \%$ against $83 \%$ in batch reactors. [5] used batch reactors to study the removal of chromium and at steady state the column inoculated with SRB removed $65 \%$ of sulfate and $95 \%$ of chromium. So far, there are two paths to precipitate metals. One is biosorption and the other is formation of metal sulfide. Heavy metal ions have been known to have toxic and inhibitory impact on SRB. So forming mental sulfide is the best way to remove heavy metals. That is to say the key point of AMD treatment is the reduction of sulfate by SRB and how to improve its efficiency. Here we report some characteristics of sulfate reduction in the cultivation of SRB and found out the relationshiping between C/S and sulfate reduction efficiency.

\section{Methods and materials}

Sampling procedure. The biological material used for different experiments was formed by a mixed culture of SRB isolated from the sludge deposited at the bottom of drainage ditch near the department producing sulphuric acid in Huangshi Daye Non-ferrous Metals Co., Ltd. [6] reported that sulfate reducers were most abundant at depths of 0 to $2 \mathrm{~cm}$ in the mud at $\mathrm{pS}^{2-}$ values of about 11 and redox potential values of -100 to $-150 \mathrm{mV}$. So samples were taken at depth of 0 to $2 \mathrm{~cm}$ in the mud right beneath the waste water to a bottle sealed with a rubber cover. The characterization of waste water was shown in table 1. 
Table 1 Chenmical analysis of the waste water above the mud

\begin{tabular}{|c|c|}
\hline Item & Value \\
\hline $\mathrm{pH}$ & 1 \\
\hline Sulfate $(\mathrm{ppm})$ & 16104.72 \\
\hline Copper $(\mathrm{ppm})$ & 427.52 \\
\hline Iron $(\mathrm{ppm})$ & 1315.32 \\
\hline Zinc $(\mathrm{ppm})$ & 171.23 \\
\hline Lead $(\mathrm{ppm})$ & 6.68 \\
\hline Cadmium $(\mathrm{ppm})$ & 3.07 \\
\hline
\end{tabular}

Isolation and enrichment of SRB. Postgate's C medium [7] was prepared for SRB enrichment in samples, and $\mathrm{pH}$ was adjusted to 7 with $\mathrm{NaOH}\left(1 \mathrm{~mol} \cdot \mathrm{L}^{-1}\right) .200 \mathrm{~mL}$ medium was added into a $250 \mathrm{~mL}$ anaerobic bottle, which was then blown with $\mathrm{N}_{2}$ for 10-15 min. After that $3 \mathrm{~g}$ mud sample was put into the medium in the anaerobic bottle blown again for 10-15 min with $\mathrm{N}_{2}$. The bottle was taken into the thermal air bath oscillator at the temperature of $35^{\circ} \mathrm{C}$ and at the speed of $120 \mathrm{rpm}$. Sulfate in the bottle was measured periodically. When Sulfate decreased sharply, it was the time for the bacterium to be inoculated to another new prepared medium with the ratio $1: 10(\mathrm{v} / \mathrm{v})$, and a parallel and blank experiment was done at the same time. The growth of SRB was measureed by the formation of black precipitates at bottom of the bottle, which also appeared on the bottle wall. In addition an unpleasant smell of hydrogen sulfide was obvious.

Culture media. Postgate's $C$ medium was used and $1 \mathrm{~L}$ medium contains $0.5 \mathrm{~g} \cdot \mathrm{L}^{-1} \mathrm{KH}_{2} \mathrm{PO}_{4}, 1.0$ $\mathrm{g} \cdot \mathrm{L}^{-1} \mathrm{NH}_{4} \mathrm{Cl}, 0.06 \mathrm{~g} \cdot \mathrm{L}^{-1} \mathrm{CaCl} \cdot 6 \mathrm{H}_{2} \mathrm{O}, 4.5 \mathrm{~g} \cdot \mathrm{L}^{-1} \mathrm{Na}_{2} \mathrm{SO}_{4}, 0.06 \mathrm{~g} \cdot \mathrm{L}^{-1} \mathrm{MgSO}_{4} \cdot 7 \mathrm{H}_{2} \mathrm{O}, 3.5 \mathrm{~g} \cdot \mathrm{L}^{-1}$ sodium lactate, $1.0 \mathrm{~g} \cdot \mathrm{L}^{-1}$ yeast extract, $1.0 \mathrm{~g} \cdot \mathrm{L}^{-1} \mathrm{CaSO}_{4}, 0.01 \mathrm{~g} \cdot \mathrm{L}^{-1} \mathrm{FeSO}_{4} \cdot 7 \mathrm{H}_{2} \mathrm{O}, 0.3 \mathrm{~g} . \mathrm{L}^{-1}$ sodium citrate and the rest was distilled water. The $\mathrm{pH}$ was adjusted to 7 with $\mathrm{NaOH}\left(1 \mathrm{~mol} \cdot \mathrm{L}^{-1}\right)$. All the components were added into flask except $\mathrm{FeSO}_{4} \cdot 7 \mathrm{H}_{2} \mathrm{O}$ and sodium citrate, and then 200mL were taken into $250 \mathrm{~mL}$ anaerobic bottle, and its $\mathrm{pH}$ was adjusted to 7. After that it was spared for 10-15 min with $\mathrm{N}_{2}$, then $\mathrm{FeSO}_{4} \cdot 7 \mathrm{H}_{2} \mathrm{O}$ and sodium citrate were added into it. At last, it was spared for 10-15 min with $\mathrm{N}_{2}$ again.

Low-sultate Reduction. Based on the preparation of Postgate's $\mathrm{C}$ medium, various amount of $\mathrm{Na}_{2} \mathrm{SO}_{4}$ was added into the medium instead of the initial $4.5 \mathrm{~g} \cdot \mathrm{L}^{-1} \mathrm{Na}_{2} \mathrm{SO}_{4}$ to make sure the concentrations of $\mathrm{SO}_{4}{ }^{2-}$ at certain stage in $200 \mathrm{~mL}$ medium in each anaerobic bottle $\left(\left[\mathrm{SO}_{4}{ }^{2-}\right]=1800\right.$ $\left.\mathrm{mg} \cdot \mathrm{L}^{-1}, 2800 \mathrm{mg} \cdot \mathrm{L}^{-1}, 3800 \mathrm{mg} \cdot \mathrm{L}^{-1}\right)$. And then all the bottles were warmed in thermal air bath oscillator at temperature of $35^{\circ} \mathrm{C}$ for $1 \mathrm{~h}$ before inoculation. After that the bacterium solution was inoculated to each anaerobic bottle with a syringe at the ratio of 1:10 and the pressure between the atmosphere and the bottle was sure to be balanced. Sulfate, $\mathrm{pH}$ and V were measured periodically, so did the parallel and blank experiments.

Analytical methods. A dry smooth measurable syringe was firstly inserted into the bottle, and the volume of the expanded gas was read and recorded. This gas was produced by the amount of bacteria solution at that time. As the bacteria solution would be extracted to do some other tests, the ratio of gas volume and bacteria solution volume at the same time was used to record the produced gas of bacteria, which could clear the error of the decreasing bacteria solution by sampling. $5 \mathrm{~mL}$ solution was extracted homogenously to measure $\mathrm{pH}$ (ORION818, USA), $\mathrm{S}^{2-}$, and $\mathrm{SO}_{4}{ }^{2-}$. At the same time the produced gas also would be extracted until the press was balanced with atmosphere. $\mathrm{V}$ was the sum of every recorded gas volume ratio. $5 \mathrm{~mL}$ solution was added into centrifugal (Xinhang, Jintan, China) tube to measure pH. Then it was centrifuged at $4000 \mathrm{rpm}$ for $10 \mathrm{~min}$. A certain volume of each clarified solution was extracted by a pipette (Dragon-med, Beijing, China) to measure the concentration of $\mathrm{S}^{2-}$ and $\mathrm{SO}_{4}{ }^{2-}$. The method of sulfate determination was Photometric method by Barium chromate using a spectrophotometer (Shimadzu, Japan) at $420 \mathrm{~nm}$ [8]. While sulfide was determined by the methylene blue formation reaction using the same spectrophotometer (Shimadzu, Japan) at $665 \mathrm{~nm}$ [9]. All the items (V, pH, sulfate and sulfide) were measured periodically. 


\section{Results and discussion}

Cultivation of SRB. Without sterilization shown in Fig. 1 the sulfate curves go down sharply and then rise up in blank experiment and first time cultivation, while in blank experiment with sterilization shown in Fig. 2 the sulfate curve didn't change obviously. [2] reported that lactate could be decomposed by MB (methanogenic bacteria) or AB (acetogenic bacteria) to produce $\mathrm{CH}_{4}$ or acetate. According to Fig.1 3, it shows that maybe MB or AB would grow at the first few hours and sulfate was absorbed by them, and only a little sulfide was produced at these few hours, proving that the reason for sulfate decrease was not by reduction but absorption by $\mathrm{MB}$ and $\mathrm{AB}$.

The curve $\mathrm{V}$ goes down on the $15^{\text {th }}$ day in Fig. 3. At that time the rate of sulfate reduction became the maximum and the rate of sulfide production also reached the top. It shows that around this time the SBR produced $\mathrm{H}_{2} \mathrm{~S}$ largely, which was dissolved in the solution. It also indicates that at that time SRB grew well. So all these phenomena point to one conclusion that the decrease of the produced gas could be a symbol of vigorous growth of SRB.

Low concentration of sulfate reduction. From Fig. 5 as we can see, the ratio of sulfate reduction reaches $85.71 \%$, although the amount of sulfate reduction is less than the others. And its $\mathrm{C} / \mathrm{S}$ ratios was about 2.0. So if the removal of sulfate reaches $80 \%$ in neutral Postgate's $\mathrm{C}$ medium with the inoculation ratio of $1: 10$, the C/S couldn't be lower than 2.0 .

When the amount of sulfate was less than $2800 \mathrm{mg} \cdot \mathrm{L}^{-1}$, the trend of accumulated volume curve didn't decrease as in Figs. 5 6. SRB was inoculated into the fresh medium with low concentration of $\mathrm{SO}_{4}{ }^{2-}$, and it could adapt and grow well. $\mathrm{H}_{2} \mathrm{~S}$ was produced swiftly, and dissolved $\mathrm{H}_{2} \mathrm{~S}$ was in the minority of the total produced $\mathrm{H}_{2} \mathrm{~S}$. So V curves didn't decrease.

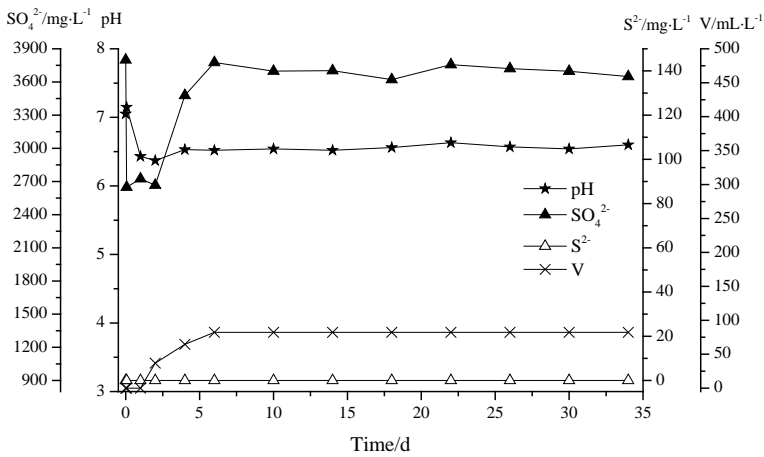

Fig.1 Blank experiment without sterilization

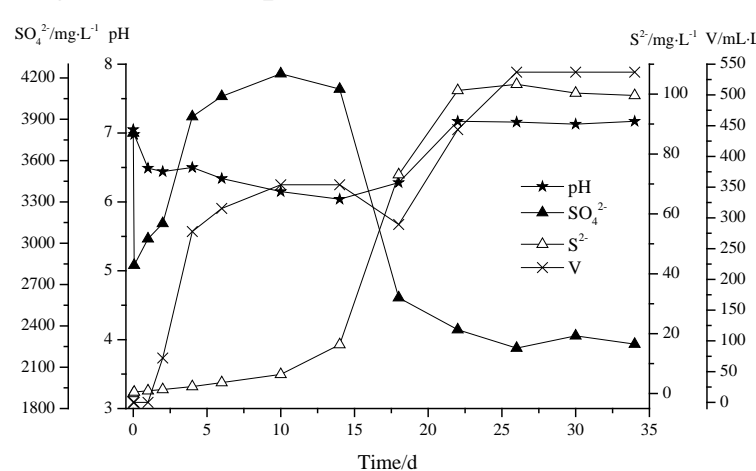

Fig.3 Cultivation of SRB for the first time

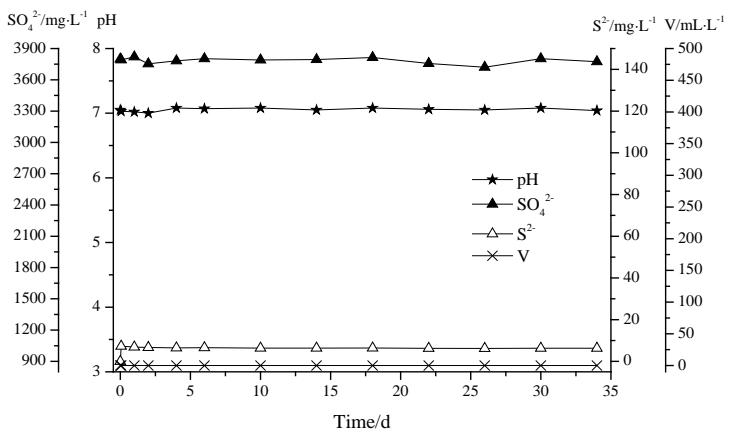

Fig.2 Blank experiment with sterilization

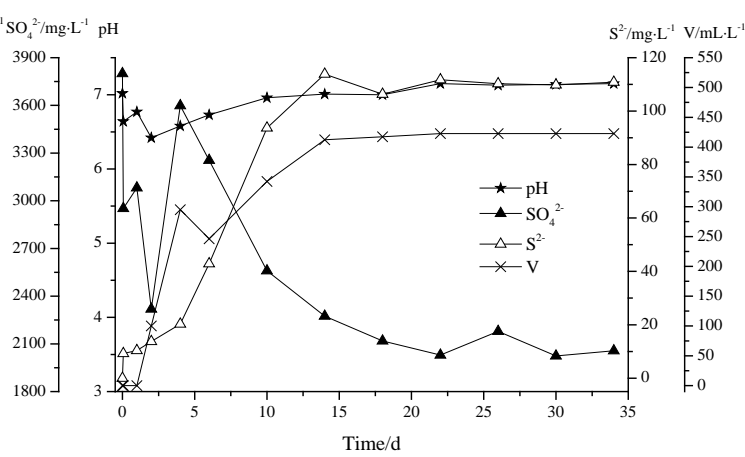

Fig.4 Cultivation for the second time

The max ratio of sulfate reduction of the next little cultivation was almost the same compared with the second time shown in Fig. 4, so the inoculation time was between the $4^{\text {th }}$ and $10^{\text {th }}$ day. 


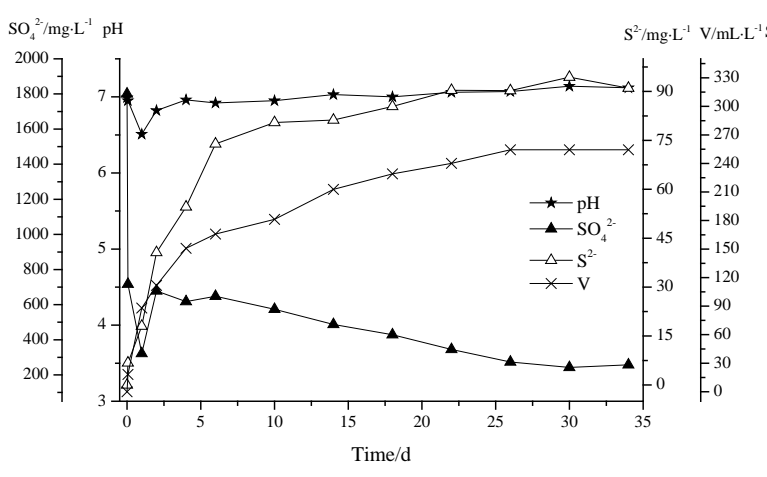

Fig. 5 Cultivation characteristics of $\mathrm{SRB}$ with initial $\mathrm{SO}_{4}{ }^{2-}$ concentration of $1800 \mathrm{mg} \cdot \mathrm{L}^{-1}$

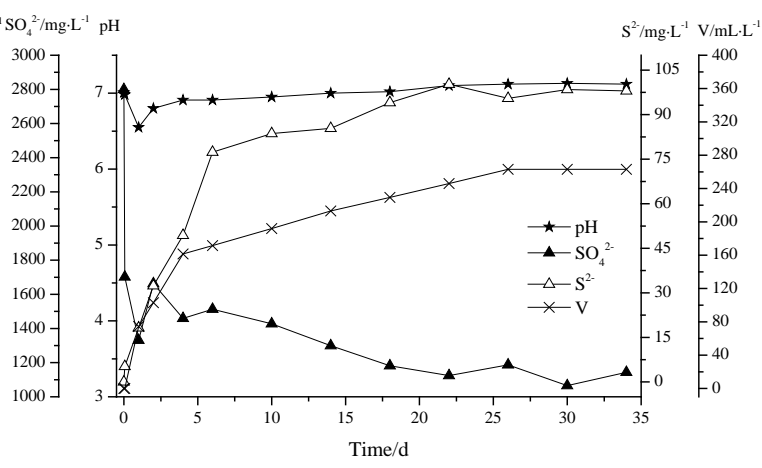

Fig. 6 Cultivation characteristics of SRB with initial $\mathrm{SO}_{4}{ }^{2-}$ concentration of 2800 $\mathrm{mg} \cdot \mathrm{L}^{-1}$

While the amount of sulfate was $3800 \mathrm{mg} \cdot \mathrm{L}^{-1}$ with the inoculation ratio $1: 10(\mathrm{v} / \mathrm{v})$, just as Fig. 4, SRB needed to self-adaption and took some time on preparing for the sulfate reduction. In this period of time $\mathrm{H}_{2} \mathrm{~S}$ produced by SRB increased gradually, and little sulfide was dissolved into solution. When the ratio of dissolved $\mathrm{H}_{2} \mathrm{~S}$ was more than the ratio of total gas produced by bacteria after sampling, the accumulated volume would decrease. As more and more $\mathrm{H}_{2} \mathrm{~S}$ was produced by SRB and less and less $\mathrm{H}_{2} \mathrm{~S}$ dissolved in solution for the balance of dissolution, the $\mathrm{V}$ curves rise up again. And it also could prove indirectly that the time when $\mathrm{V}$ curves decrease would be considered as the symbol of great sulfate reduction and vigorous growth of SRB.

\section{Conclusions}

Some characteristics were reported in cultivation of SRB, which was isolated from sludge deposited at the bottom of drainage ditch near the department producing sulphuric acid in Huangshi Daye Non-ferrous Metals Co., Ltd in HuBei China. It is a sulfate-tolerant bacteria. Without sterilization other bacteria like $\mathrm{AB}$ or $\mathrm{MB}$ may absorb sulfate and release sulfate after their death because of $\mathrm{H}_{2} \mathrm{~S}$ produced by SRB. When C/S ratio was more than 2.0, the sulfate removal ratio could reach $80 \%$ at the inoculation ratio $1: 10$ in Postgate's $C$ medium. As the C/S ratio became lower and lower, the removal ratio of sulfate was lower and lower. The decrease of accumulated gas volume may be a symbol of the vigorous growth of SRB when sulfate was $3800 \mathrm{mg} \cdot \mathrm{L}^{-1}$, while it was less than $2800 \mathrm{mg} \cdot \mathrm{L}^{-1}$ the SRB grow vigorously after inoculation.

\section{Acknowledgement}

The authors are grateful to the financial support of the Doctoral scientific research funds of Jianghan University.

\section{References}

[1] Alazard, D., Joseph, M., Battaglia-Brunet, F., Cayol, J. L., \& Ollivier, B. (2010). Desulfosporosinus acidiphilus sp. nov.: a moderately acidophilic sulfate-reducing bacterium isolated from acid mining drainage sediments.Extremophiles, 14(3), 305-312.

[2] Gibson, G. R. (1990). Physiology and ecology of the sulfate - reducing bacteria. Journal of Applied Bacteriology, 69(6), 769-797.

[3] Sierra-Alvarez, R., Karri, S., Freeman, S., \& Field, J. (2006). Biological treatment of heavy metals in acid mine drainage using sulfate reducing bioreactors. Water Science \& Technology, 54(2), 179-185.

[4] Viggi, C. C., Pagnanelli, F., Cibati, A., Uccelletti, D., Palleschi, C., \& Toro, L. (2010). Biotreatment and bioassessment of heavy metal removal by sulfate reducing bacteria in fixed bed 
reactors. Water research, 44(1), 151-158

[5] Pagnanelli, F., Viggi, C. C., Cibati, A., Uccelletti, D., Toro, L., \& Palleschi, C. (2012). Biotreatment of $\mathrm{Cr}$ (VI) contaminated waters by sulfate reducing bacteria fed with ethanol. Journal of Hazardous materials, 199, 186-192.

[6] Cappenberg, T. E. (1974). Interrelations between sulfate-reducing and methane-producing bacteria in bottom deposits of a fresh-water lake. I. Field observations. Antonie van Leeuwenhoek, 40(2), 285-295.

[7] Postgate, J. R. (1979). The sulfate-reducing bacteria. CUP Archive.

[8] Jing, C., Ping, Z., \& Mahmood, Q. (2010). Influence of various nitrogenous electron acceptors on the anaerobic sulfide oxidation. Bioresource technology, 101(9), 2931-2937.

[9] Dou, J., Liu, X., Hu, Z., \& Deng, D. (2008). Anaerobic BTEX biodegradation linked to nitrate and sulfate reduction. Journal of Hazardous Materials,151(2), 720-729. 